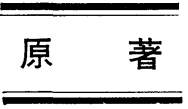

\title{
甲状腺穿刺吸引細胞診における多パラメーター 解析の診断学的意義
}

\author{
岐皁大学医学部第 3 内科 ${ }^{12}$, 岐阜日赤病院外科 ${ }^{2)}$, 岐阜大学医学部第 1 病理 ${ }^{3)}$ \\ 島 寛人 ${ }^{1)}$ 三浦 清 ${ }^{1)}$ 多羅尾 信 $^{2}$ 高橋 正宜 $^{3)}$
}

各甲状腺疾患について, 細胞診所見に加えて核内細胞質封入体, 細胞核長径, 顕微分光測光法に よる核 DNA 量および細胞総蛋白量の計測を行った. 核長径は, 乳頭癌 11 例で, $7.8 \pm 1.4 \mu$ (mean \pm SD) から $9.9 \pm 1.6 \mu$, 滤胞癌で, $8.3 \pm 1.3 \mu$ および $9.4 \pm 1.9 \mu$, 未分化癌で, $10.7 \pm 2.9 \mu$, 髄様癌で $8.5 \pm 1.6 \mu, 9.0 \pm 1.8 \mu$ といずれも, 腺腫, 腺腫様甲状腺腫に比し増大したが, 慢性甲 状腺炎でも, その多形性を反映し増大傾向が示された. 核内細胞質封入体は, 良性疾患, 濾胞癌に は認められず, 乳頭癌 11 例中 10 例, 髄様癌 2 例中 1 例, また, 未分化癌はその 1 例に陽性を示し た. 乳頭癌において, 癌細胞に占めるその出現頻度は, それぞれ $0.4 \%$ から $2.6 \%$ で, 出現頻度に 関して他型のそれと有意差はなかった。核 DNA 量: 細胞総蛋白量は, 乳頭癌で, 計測全例の平均 が $2.51 \pm 0.90 \mathrm{AU}: 4.01 \pm 2.35 \mathrm{AU}$, 滤胞癌で $2.72 \pm 0.79 \mathrm{AU}: 2.78 \pm 0.99 \mathrm{AU}$, 未分化癌で 6.20 $\pm 4.39 \mathrm{AU}: 6.70 \pm 4.81 \mathrm{AU}$ と, 腺腫例の平均 $2.28 \pm 0.65 \mathrm{AU}: 2.91 \pm 1.37 \mathrm{AU}$ に比較し, 濾胞 癌で細胞総蛋白量の減少を認めた以外はいずれも有意 $(\mathrm{P}<0.001)$ に增加した. これらの客観的パ ラメーターの解析は, 甲状腺腫瘍の鑑別診断に有意義と考えられる.

Key words : Thyroid—DNA content-Cellular protein content-CytofluorometryIntranuclear cytoplasmic inclusion

\section{は じめに}

甲状腺腫に㧍ける診断には触診をはじめ, 血清生化 学, 各種の画像診断法が用いられ, 特に画像解析の進歩 は著しい効果をあげているが，その確定診断としては，

\footnotetext{
Diagnostic evaluation of multi-parameter analysis in fine needle aspiration biopsy cytology of the thyroid

Hiroto SHIMA, M.D. and Kiyoshi MIURA, M.D.

3 rd Department of Internal Medicine, Gifu University School of Medicine

Makoto TARAO, M.D.

Department of Surgery, Gifu Red Cross Hospital

Masayoshi TAKAHASHI, M.D., F.I.A.C.

1 st Department of Pathology, Gifu University School of Medicine

論文別刷請求先 函502 岐阜市岩倉町 3 の36 岐阜日赤病院 検査部病理 島 宽人

昭和 60 年 5 月 24 日受付

昭和 60 年 12 月 20 日受理
}

今なお病理形態学的所見に負うところが多い.

従来, 甲状腺腫の病理組織診断法としては, Open biopsy, Vim-Silverman 針による Needle biopsy などが行 われてきた. これらの生検法は, それぞれ, 観血的外科 手術を要したり, 盲目的生検法では合併症の危険を伴う ものである ${ }^{21)}$. 近年, これらにかわり, ほぼ $1 \mathrm{~mm}$ 径の 細穿刺針を使用し, 安全かつ簡便な細穿刺吸引生検細胞 診 Needle Aspiration Biopsy Cytology (以下, ABC) が 用いられ，その有用性が広く認識されるようになった. しかし, 甲状腺癌の $\mathrm{ABC}$ では, 細胞異型が軽度で, し ばしば良性, 悪性の診断に苦慮する症例に遭遇する. そ こで, 従来の光顕的細胞所見に加え, 各種の客観的パラ メーター解析による診断へのアプローチが, 他臓器癌と 同様に，甲状腺癌においても試みられてきた1,14,15,20,23, ${ }^{26,30)}$.とりわけ, Caspersson ${ }^{5)}$ とより始められた核 DNA 量に関する顕微分光測光法は, その後 Fujita ら ${ }^{7)}$ によ り, 特異性の高い螢光測光法に改良され, 広く腫瘍学に 
表 1 研究対象例の病理組織学的分類

\begin{tabular}{|c|c|}
\hline 慢性甲状腺炎 & \\
\hline 腺腫様甲状腺腫 & \\
\hline 良性腫崵 & 3 \\
\hline 濾胞腺腫 & 37 \\
\hline コロイド腺腫 & 33 \\
\hline 管状腺腫 & 4 \\
\hline 悪性腫瘍 & 1 \\
\hline 乳頭癌 & 11 \\
\hline 濾胞癌 & 2 \\
\hline 末分化癌 & 1 \\
\hline 䯣様癌 & $2^{*}$ \\
\hline 計 & 5 \\
\hline
\end{tabular}

*捺印標本

おいて，診断のみならず，予後との関連2)などにおいて 応用されており，甲状腺癌の細胞診における有用性も報 告されてきた ${ }^{1,23,30)}$. しかし, 核 DNA 量のみからは, 絶対的基準とはしがたいのが実情である.

今回著者らは, 甲状腺の $\mathrm{ABC}$ について, その細胞診 所見，特に核径，核内細胞質封入体 (以下, 核内封入体) 出現頻度なぞの通常の観察法に加えて, 螢光顕微分光測 光法による核 DNA 量と細胞総蛋白量 (以下, 総蛋白量) の同時測光を行い，その診断学的意義について検討を加 えた.

\section{研究対象ならびに方法}

\section{I. 研究対象}

1982 年より 1983 年までの間に岐阜日赤病院におい て，ABC を行い，外科手術を施行した甲状腺腫 59 症例 について, 得られた細胞材料を用いた（表 1 ).これら の症例中甲状腺腫瘍の病理組織学的分類は, 甲状腺癌取 扱い規約 ${ }^{19}$ により行った.

\section{II. 穿刺吸引生検細胞診}

穿刺法は $21 \mathrm{G}$ (外径 $0.81 \mathrm{~mm}$ ) あるいは $22 \mathrm{G}$ (外径 $0.7 \mathrm{~mm}$ ) の注射針と, $10 \mathrm{~m} l$ 注射筒および細胞診用吸引 ピストルを用いた，患者は仰臥位とし，頸部を伸展さ せ, 穿刺時の讌下運動を禁じた. 穿刺局所をアルコール 消毒後, 非麻酔下に, 左手指間に腫瘤を固定し, 穿刺吸 引を行った．抜去時陰圧を回復し，針内腔に得られた細 胞材料は, 注射筒に入れた小量の生理食塩水により, 注 射針より静かに圧出し, 光顕用塗抹標本を作製, ただち に $95 \%$ エタノールにより湿固定を行った. Giemsa 染色 用標本は, 冷風乾燥固定を行った. 光顕用の染色法に は, Papanicolaou 染色 (以下, Pap. 染色), PAS 反応, Giemsa 染色を用いた.
細胞診所見は, 各染色標本を対比させ観察した. 核長 径, 核内封入体の計測は, Pap. 染色標本上の細胞を対物 油浸 100 倍を使用し，MTV テレビ装置 (Olympus) お よび対物ミクロメーターにより行った。核長径は， 1 視 野 10 個を限度とし, おのおの 100 個計測, 細胞診所 見 でのクロマチン構造は, 細顆粒状, 細網状, 粗顆粒状, 粗網状の 4 型に分類した ${ }^{27)}$. 核内封入体の計測は, 細胞 1,000 個あたりの出現頻度およびその直径, 核長径に占 める核内封入体の割合 (対核径比), 複数を有する割合, 組織型別出現率などの検討を行った.

\section{III. 螢光顕微分光測光法による各甲状腺疾患の核 DNA 量および総蛋白量の定量}

螢光染色による標本背景の非特異的共染を避けるた め, また, 適当な細胞分散のため, 穿刺材料をソルビト 一ル加乳酸リンゲル液 $10 \mathrm{~m} l$ 中に静かに圧出し, 数回の シリンジング操作後, 1,500 回転, 5 分間遠沈. 血液, 霊 胞液などの混入の多い検体は, 同様の洗榄操作を数回行 った. 得られた沈渣を無螢光スライドグラスに可能なか ぎり薄く塗抹し，ただちに Böhm ら ${ }^{4)}$ の固定液 (メタ) ール：ホルマリン: 眽酸 $=85: 10: 5)$ で室温 60 分間固 定. 固定後 $100 \%$ エタノールで数回洗滌後, Fukuda ら ${ }^{8)}$ の pararosanilin-Feulgen, ninhydrin-acriflavine-Schiff 反応による DNA-蛋白螢光重染色を行った. 染色標本を 紫外線照射装置 LSPI (Olympus) により, blue 励起光 および, green 励起光でおのおの 10 時間の後照射を行 い, 非特異螢光を排除 ${ }^{8,11)}$, 落射螢光顕微測光顕微鏡 QRFL (Olympus) および対物螢光油浸レンズ 100 倍を 用い，各標本上の上皮細胞 $50 \sim 410$ 個の核 DNA 量と総 蛋白量の同時測光定量を行った．核 DNA 量の定量は, green excitation filter $545 \mathrm{~nm}$, barrier filter $580 \mathrm{~nm}$, 総蛋白量の定量は, blue excitation filter $405 \mathrm{~nm}$, barrier filter $515 \mathrm{~nm}$ をおの㧍の使用し，マイクロコンピュ 一タにて散布図を作製した。 なお，対照として同一標本 上の多核白血球 30 個を測定し，その核 DNA 量（relative DNA content), 総蛋白量 (relative protein content）を扔の扔の $2 \mathrm{c}, 2 \mathrm{p}$ として表した．また，得られ た各甲状腺疾患の全 2 次元データをマイクロコンピュー 夕 FM 11 (富士通) を用い解析し, Mahalanobis の汎距 離法*による $95 \%$ 等確率長円 $\left(\mathrm{D}^{2}\right)$ を示す 2 変量管理図 を作製した。

$$
\begin{aligned}
& * \mathrm{D}^{2}=\frac{\mathrm{U}_{1}^{2}+\mathrm{U}_{2}^{2}-2 \gamma \mathrm{U}_{1} \mathrm{U}_{2}}{1-\gamma^{2}} \text { ただし } \mathrm{U}_{1}^{2}=\frac{\left(x_{1}-\mu_{1}\right)^{2}}{\sigma^{2}}, \\
& \mathrm{U}_{2}^{2}=\frac{\left(x_{2}-\mu_{2}\right)^{2}}{\sigma^{2}} \\
& \left(x_{1}=\text { 核 DNA 量, } x_{2}=\text { 総蛋白量, } \gamma=\right.\text { 相関係数, } \\
& \left.\mu=\text { 平均, } \sigma^{2}=\text { 分散 }\right)
\end{aligned}
$$




\section{結果}

\section{I. 穿刺吸引細胞診所見}

1. 各甲状腺疾患の穿刺吸引細胞診所見

1) 腺腫 (adenoma)

滤胞腺腫 (follicular adenoma) は 37 例で, その組織 学的亜分類は，コロイド腺腫 (colloid adenoma) 33 例, 管状腺腫（tubular adenoma）４例であった。囊胞変性 は, コロイド腺腫 17 例，管状腺腫 1 例にみられた。穿 刺吸引に際し，これら囊胞変性例では，しばしば半流動 状, 暗褐色の血液変性物が採取された。 これらの標本で は, 上皮細胞成分は少なく, また, 変性による上皮細胞

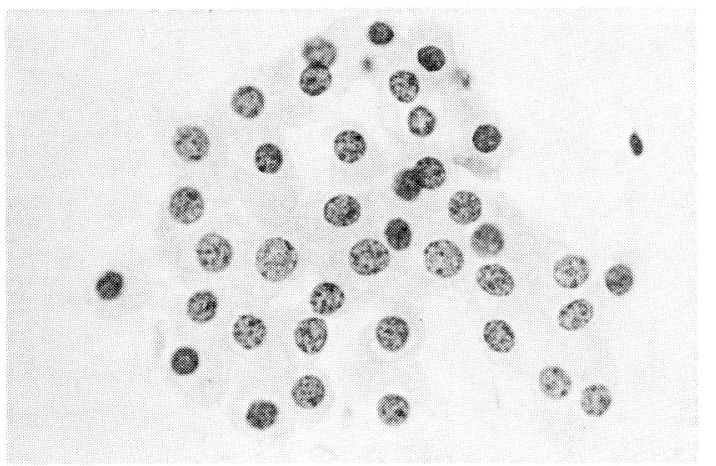

写真 1 濾胞腺腫. 小型類円形核より成るシート状配列 (Pap. 染色, ×857)
の核濃縮, 細胞質の空胞変性などがみられた。他の細胞 成分では, 多数の組織球性泡沫細胞が特徴的であった。 非囊胞変性例では, 背景には, 赤血球および少数のリン パ球がみられる程度であり, 細胞壞死物質などは認めら れなかった. コロイド腺腫では, PAS 陽性を示すコロイ ドの増加があり, 細胞集塊内あるい集塊外に認められ た. 細胞集塊は小型で, シート状配列を示した（写真 1). 5 例のコロイド腺腫において, 細胞数 100 個以上の 大型集塊がみられた。また，これらの例では採取される 細胞集塊数も増加した. 管状腺腫では，4例とも細胞集 塊は小型で， 3 例では小型滤胞状配列を示寸小型集塊も よく認められた。孤立性上皮細胞は全例に扮いてみられ たが，そのほとんどは裸核状を呈した。細胞集塊におけ る個々の細胞所見は, 細胞質は薄く淡青色で, 細胞境界 は不鮮明で亦った。核形は類円形で，核長径は $5.5 \pm$ $0.7 \sim 7.2 \pm 0.7 \mu$ (mean $\pm \mathrm{SD})$ で, 大小不同は少なかっ た（図 1)，核小体は，全例において青染し，単一で $2 \mu$ 以下であったが, 一部 2 次変性に起因寸る, 核小体膨大 などの榜異型を示すものがみられた (写真 2).クロマチ ン構造は㧍㧍む数細顆粒状で均一な分布を示したが，一 部変性による粗顆粒状凝集が認められた.

2) 腺腫様甲状腺腫 (adenomatous goiter)

3 例ともコロイド量の増加傾向を認めた。細胞集塊法 100 個以下の細胞よりなる中等度の集塊が多く, シート 状の規則性配列を示した．また，一部，少数の濾胞状配 列を呈する小型集塊も認就れた。個々の細胞所見は,

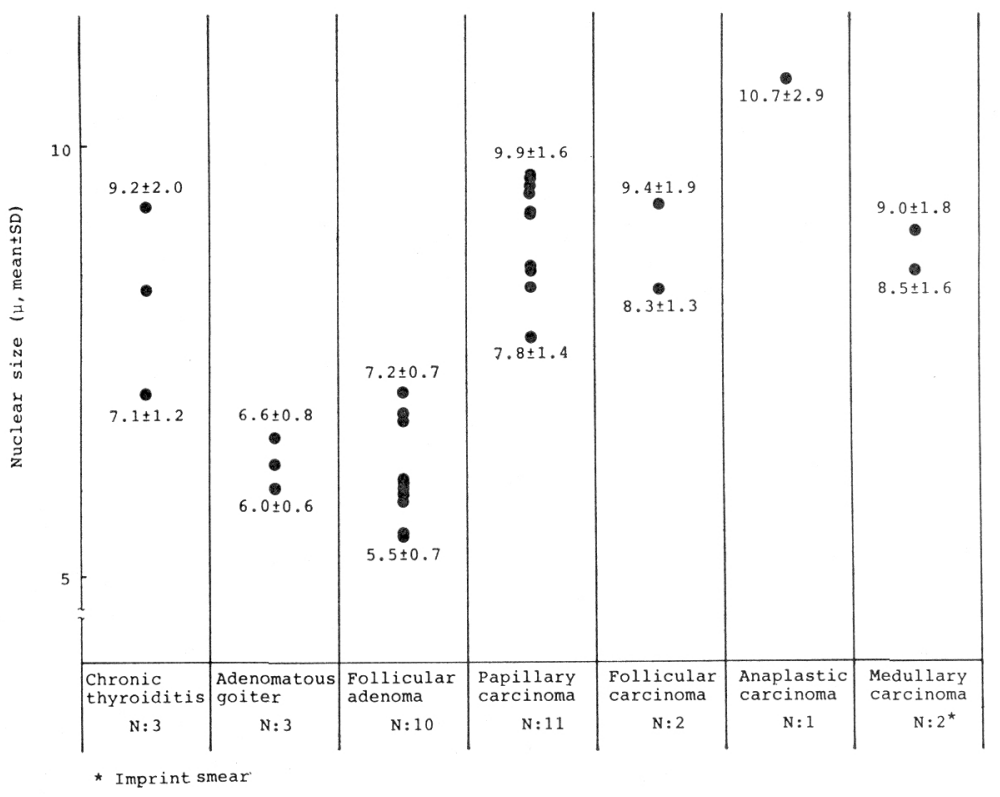

図 1 Pap. 染色禋本に㧍ける各甲状腺疾患の細胞核長径の分布 


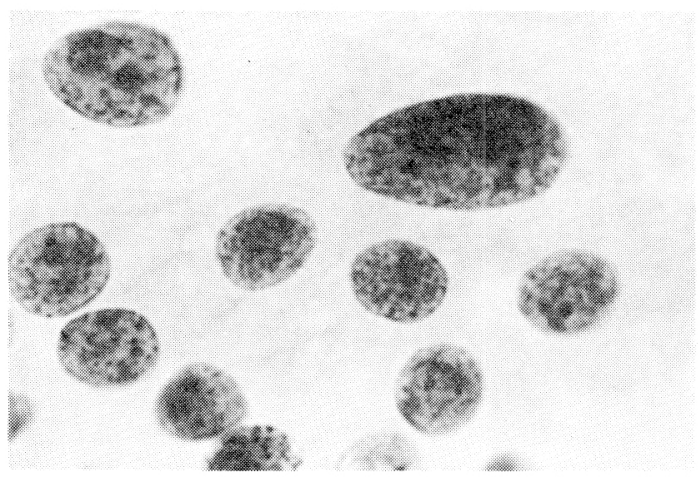

写真 2 濾胞腺腫. シート状配列老構成する個々の核の核小 体は赤染しやや目立つ（Pap. 染色， $\times 2,142 ）$

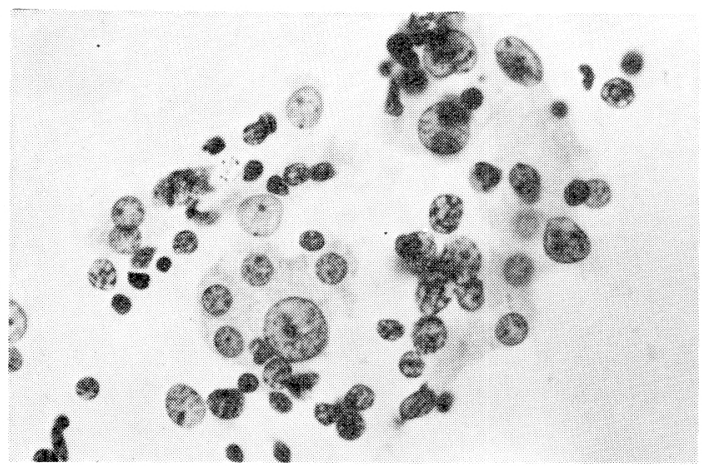

写真 3 慢性甲状腺炎. 多形性走示寸好酸性変性上皮 (Pap. 染色, $\times 857)$

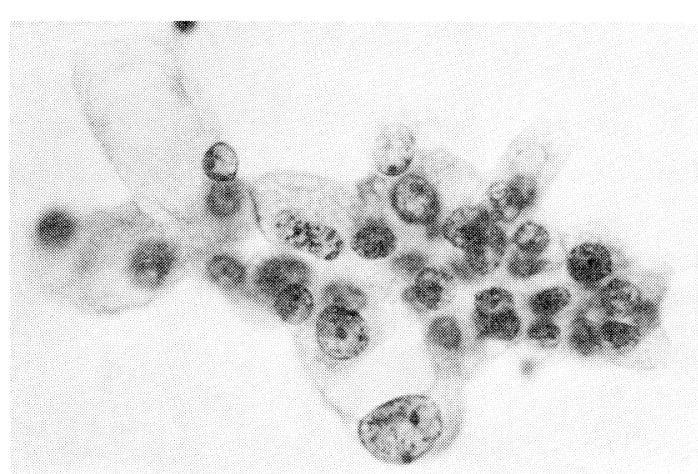

写真 4 乳頭癌. 著明な細胞質空胞变性上皮 (Pap. 染色, $\times 857$ )

核は類円形を呈し，核長径は $6.0 \pm 0.6 \sim 6.6 \pm 0.8 \mu$ で 均一性であった (図 1). 核小体はいずれの例でも目立た ず，クロマチン構造は細顆粒状, 均一分布を呈した. 以 上の細胞診所見から，腺腫様甲状腺腫と滤胞腺腫との鑑 別は困難であった。

3）慢性甲状腺炎 (chronic thyroiditis) 細胞診所見では，3例いずれにも，多数のリンパ球，

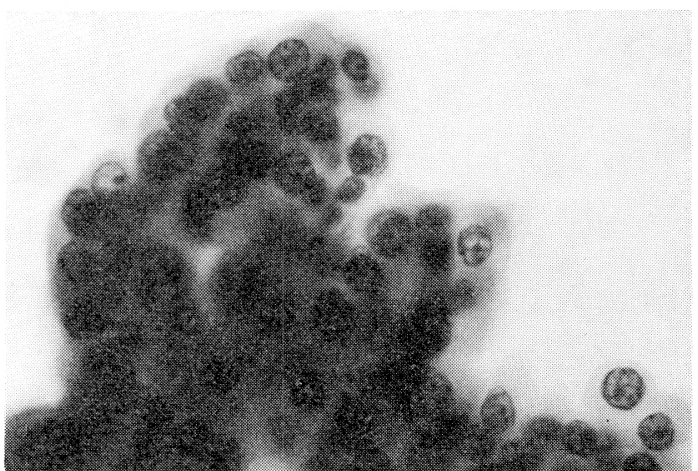

写真 5 乳頭癌. 乳頭状配列走示寸細胞集塊 (Pap. 染色, $\times 857)$

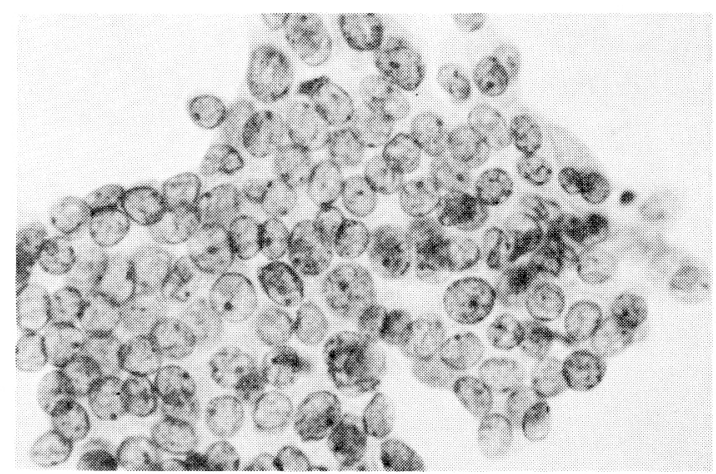

写真 6 乳頭癌. 小型均一性の核よりなる密な魚鱗状配列 (Pap. 染色, $\times 857)$

形質細胞のほか, リンパ濾胞由来の大型胚中心細胞が特 徵的に出現した。上皮細胞は集塊をなし，核の軽度ない し中等度の大小不同伴らシート状配列を示した。 3 例 中 2 例では, 少数の小型滤胞状配列もみられた. 濾胞上 皮では，細胞質は豊富で，核は類円形を呈したが，2 例 では，滤胞上皮の好酸性変性を認めた。これら好酸性変 性細胞の細胞質はさらに豊富で顆粒状を呈し，しばしば 長径 $15 \mu$ 以上に達する大型核と, 肥大赤染性, 単一性 の核小体存した. クロマチン構造は細顆粒状均一分布

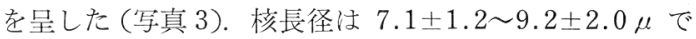
あった(図 1).

4) 乳頭癌 (papillary carcinoma)

11 例中 2 例では囊胞変性を認め, これらの例の細胞診 所見では, 組織球性泡沫細胞, リンパ球, 多核白血球な どが出現し, ときに癌細胞の著明な空胞変 性 (写真 4) や，細胞質の PAS 陽性所見などを認めた，囊胞変性を 示さない 9 例ではいずれも, 腺腫例に比較し, cellularity が高く, 結合性の強い大型の細胞集塊が多数出現し た。乳頭状配列 (写真 5) は, いずれの例でも認められた が，9例中 6 例ではむろ，核密度の高いシート状配列 
表 2 甲状腺悪性腫瘍の細胞学的所見

\begin{tabular}{|c|c|c|c|c|c|c|c|c|c|c|}
\hline Case & & 年齢，性 & $\begin{array}{l}\text { 出 現 } \\
\text { 細胞数 }\end{array}$ & $\begin{array}{c}\text { 細胞集塊 } \\
\text { の大きさ }\end{array}$ & 配 列 & $\begin{array}{l}\text { vertical } \\
\text { chromatin } \\
\text { ridge }\end{array}$ & 核小体数 & $\begin{array}{l}\text { 細胞質空 } \\
\text { 胞 変 性 }\end{array}$ & $\begin{array}{l}\text { 細胞壊 } \\
\text { 死物質 }\end{array}$ & $\begin{array}{l}\text { 多 核 } \\
\text { 巨細胞 }\end{array}$ \\
\hline \multirow[t]{11}{*}{ 乳 頭 癌 } & 1 & $29, \mathrm{~m}$ & + & 小 & pap & - & 1 & +++ & + & - \\
\hline & 2 & $30, \mathrm{f}$ & + & 小 & pap & ++ & 1 & $+t$ & - & + \\
\hline & 3 & $44, \mathrm{f}$ & +++ & 中 & sht $>$ pap & - & 1 & + & - & - \\
\hline & 4 & $36, \mathrm{f}$ & + & 小 & sht $>$ pap & ++ & $1 \sim 2$ & - & - & + \\
\hline & 5 & $31, \mathrm{f}$ & + & 大 & sht $>$ pap & $+t+$ & 1 & - & - & + \\
\hline & 6 & $48, \mathrm{f}$ & +++ & 中 & pap $>$ sht & +++ & $1 \sim 3$ & + & + & $+t$ \\
\hline & 7 & $27, \mathrm{~m}$ & +++ & 大 & sht $>$ pap & + & $1 \sim 2$ & + & + & + \\
\hline & 8 & $35, \mathrm{f}$ & +++ & 大 & sht $>$ pap & ++ & 1 & - & - & + \\
\hline & 9 & $76, \mathrm{f}$ & $++t$ & 大 & pap > sht & ++ & 1 & - & - & - \\
\hline & 10 & $42, \mathrm{f}$ & +++ & 大 & pap $>$ sht & ++ & 1 & - & - & - \\
\hline & 11 & $72, \mathrm{f}$ & +++ & 大 & sht $>$ pap & ++ & $1 \sim 3$ & - & - & - \\
\hline \multirow[t]{2}{*}{ 濾 胞‘癌 } & 1 & $56, \mathrm{f}$ & +++ & 小 & sht $>$ fol & - & $1 \sim 3$ & - & - & - \\
\hline & 2 & $28, \mathrm{f}$ & +++ & 中 & $f_{o l}>\operatorname{sht}$ & - & 1 & - & - & - \\
\hline 未分化癌 & 1 & $56, \mathrm{~m}$ & +++ & 小 & crow $>$ sht & + & $1 \sim 5$ & + & ++ & - \\
\hline
\end{tabular}

$\mathrm{m}$ : 男性, $\mathrm{f}$ : 女性。細胞集塊の大きさ, 小: <50, 中 : 50 100, 大 : > 100. 配列, pap : 乳頭状, fol: 滤胞状, sht: シート状, crow: 不整重積状。一：認めず, + : 少数, ++ : 中等度, +++ : 多数

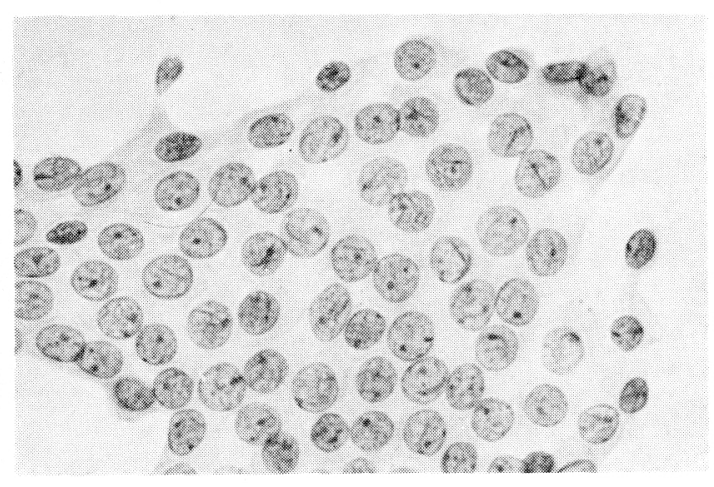

写真 7 乳頭癌. 癌細胞核にみられたクロマチンの線状凝集 (vertical chromatin ridge) (Pap. 染色, ×857)

(写真 6) が多く出現した（表 2). これらのシート状配列 を呈する細胞集塊では, N/C 比は高く, 良性のそれとは 明らかな差を示した。いずれの例でも裸核状細胞もよく 認められた。個々の細胞の核は, 核形不整, 多核などは

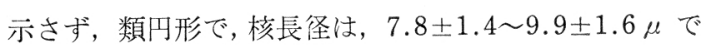
あった（図 1). 癌細胞核に扮けるクロマチンの線状凝集 (vertical chromatin ridge, 写真 7) は, 11 例中 9 例に よく認められた (表 2). クロマチン構造は, 細顆粒状か ら細網状を呈し, 変性の強い細胞では粗顆粒状を示し た. 11 例中 6 例でしばしば赤染する 1 ～個の核小体を 認めたが，大きさは $2 \mu$ 以下であった. 多核巨細胞は，

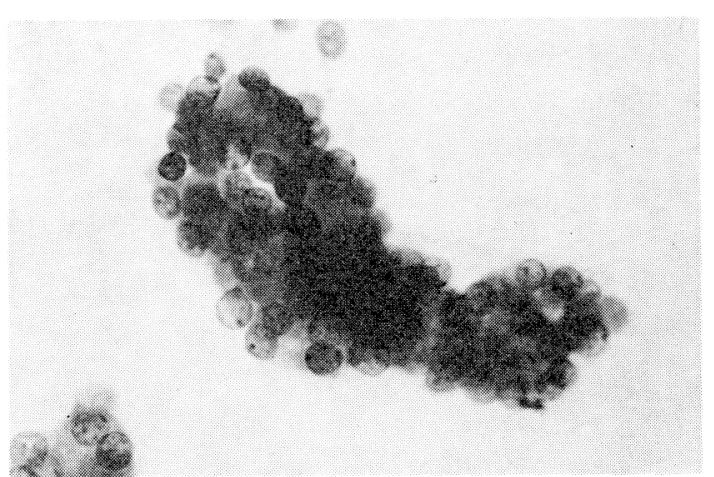

写真 8 濾胞癌. コロイドを含む小型濾胞状配列 (Pap. 染色, ×857)

11 例中 6 例に出現した. ほかの甲状腺悪性腫瘍も含め, これらの $\mathrm{ABC}$ における所見を表 2 に示した.

5) 濾胞癌 (follicular carcinoma)

2 例とも cellularity は高く, 細胞集塊は小型濾胞状か ら大型シート状配列を示すものまでさまざまであった。 組織学的に索状から小型濾胞状構造子示す例では, 重積 性のある滤胞状の細胞集塊がタられた（写真 8).シート 状集塊では, 腺腫例のそれに比し, 高い細胞密度および, 極性の不整な配列が認められた (写真 9 ). 組織学的に高 分化な 1 例では, 腺腫に比し, 核径の増大を示すもの の, 細胞集塊もシート状配列が主で, 極性の乱れもな 


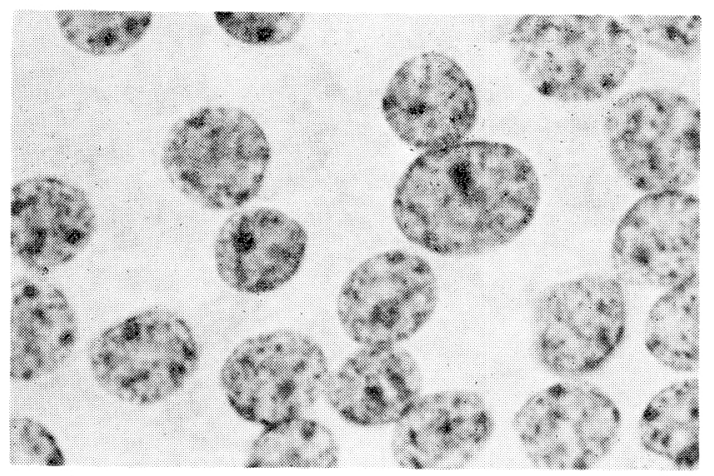

写真 9 濾胞癌. 極性の不整なシート状配列 (Pap. 染色, $\times 2,142)$

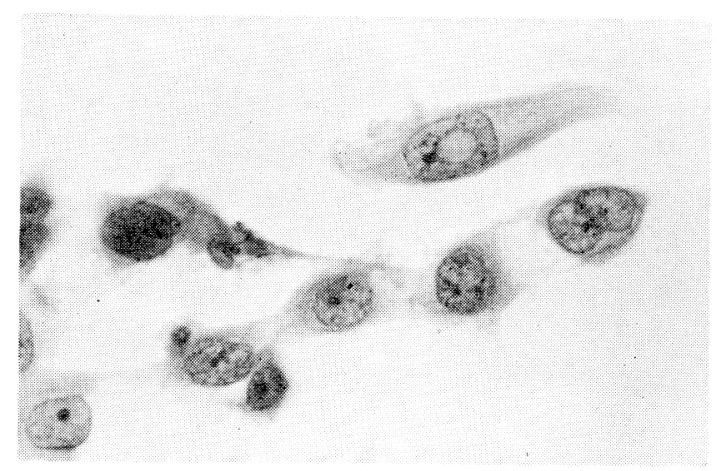

写真 10 未分化癌. 紡鍾形を呈する癌細胞の核周囲明庭抒 よび核内細胞質封入体 $($ Pap. 染色, ×857)
く, 個々の核所見も, 核異型, 核小体肥大などは認めら れないところから，なお鑑別は困難であった，核長径は それぞれ $8.3 \pm 1.3 \mu, 9.4 \pm 1.9 \mu$ であった(図 1). 核小 体は不明瞭で, クロマチン構造は細顆粒状で均一分布を 呈した。

6) 未分化癌 (anaplastic carcinoma)

組織学的には多形細胞癌で, その $\mathrm{ABC}$ では, 多数の 異型細胞が出現し，小型で結合性疎な不整細胞集塊のほ か, 孤立性癌細胞も多数認められた。細胞質は比較的豊 富で, 紡錘形を呈し, 空胞変性や，核周囲明庭もみられ た. 多核化も目立ち, 核形も円形から不整形上多様であ り，核長径は $10.7 \pm 2.9 \mu$ (図 1) で, 著明な大小不同を 示した。 クロマチンは, 細網状から粗網状で, 不均一な

写真 11 乳頭癌. 核内細胞質封入体 (Pap. 染色, $\times 2,142)$

表 3 各甲状腺悪性腫崵における核内細胞質封入体の出現頻度とその性状

\begin{tabular}{|c|c|c|c|c|c|}
\hline Case & & 頻度 (\%) & 個数 $(\%)^{*}$ & $\begin{array}{c}\text { 大ききさ } \\
(\text { mean } \pm \mathrm{SD}, \mu)\end{array}$ & 対核径此 \\
\hline \multirow[t]{11}{*}{ 乳頭癌 } & 1 & 2.5 & $1 \sim 2(12)$ & $4.1 \pm 1.8$ & 0.50 \\
\hline & 2 & 1.6 & $1 \sim 2(6)$ & $3.4 \pm 1.2$ & 0.46 \\
\hline & 3 & 1.3 & $1 \sim 2(8)$ & $3.6 \pm 1.0$ & 0.38 \\
\hline & 4 & 1.0 & $1 \sim 2(10)$ & $5.0 \pm 1.8$ & 0.52 \\
\hline & 5 & 2.6 & $1 \sim 5(8)$ & $4.6 \pm 1.3$ & 0.51 \\
\hline & 6 & 1.4 & $1 \sim 4(14)$ & $5.2 \pm 1.9$ & 0.51 \\
\hline & 7 & 0.6 & $1 \sim 2(17)$ & $3.1 \pm 1.1$ & 0.38 \\
\hline & 8 & 1.3 & $1 \sim 2(8)$ & $4.5 \pm 1.7$ & 0.50 \\
\hline & 9 & 0.4 & $1 \sim 2(25)$ & $4.1 \pm 1.6$ & 0.42 \\
\hline & 10 & 0.5 & $I \quad(0)$ & $3.4 \pm 1.6$ & 0.35 \\
\hline & 11 & 0 & & & \\
\hline 平均 & & 1.3 & $1.1(9)$ & $4.2 \pm 1.7$ & 0.45 \\
\hline \multirow[t]{2}{*}{ 濾 胞 癌 } & 1 & 0 & & & \\
\hline & 2 & 0 & & & \\
\hline 未分化癌 & 1 & 0.4 & $1 \quad(0)$ & $14.5 \pm 11.0$ & 0.76 \\
\hline \multirow[t]{2}{*}{ 髄 様 癌 } & $1^{* *}$ & 4.4 & $1 \sim 5(41)$ & $5.1 \pm 2.8$ & 0.51 \\
\hline & $2^{* *}$ & 0 & & & \\
\hline
\end{tabular}

${ }^{*} 2$ 個以上の核内細胞質封入体を有する頻度， **捺印標本 
分布を示した. 核小体はしばしば肥大赤染し，不整形で 1〜5 個有した（写真 10 ).

2. 各甲状腺疾患における核内封入体の検討

核内封入体は, Pap. 染色標本において, 核内に核小体 とは明らかに異なり, 境界明瞭で, 辺縁は核縁類似所見 を呈する円形ないし類円形の灰青緑色から灰青色に染ま る構造物である (写真 11). Giemsa 染色では, 細胞質と 同程度ないしやや明るく好塩基性に染色され, PAS 反応 では陰性であった，また，多くは核内に単一に認められ たが，ときに複数を有する細胞もあり, 最多は, 乳頭癌 および髄様癌で, おのおの 5 個認められた (表 3 ). 各甲 状腺疾患別のその出現率は, 乳頭癌 11 例中 10 例に, 未

表 4 各甲状腺疾患における核内細胞質封入体の 組織型別出現率

\begin{tabular}{lcc}
\hline \hline \multicolumn{1}{c}{ 組 織 型 } & 例数 & 出現率 $(\%)$ \\
\hline 慢性甲状腺炎 & 3 & 0 \\
腺腫様甲状腺腫 & 3 & 0 \\
濾胞腺腫 & 37 & 0 \\
乳頭癌 & 11 & 91 \\
濾胞癌 & 2 & 0 \\
未分化癌 & 1 & 100 \\
髄様癌 & $2^{*}$ & 50 \\
\hline
\end{tabular}

*捺印標本
分化癌の 1 例および髄様癌 2 例中の 1 例に認められた が，滤胞癌およびほかの良性疾患では陰性であった（表 4). 陽性例について, 癌細胞 1,000 個あたりのその頻度 と直径, 対核径比などの計測值（表 3) では, 乳頭癌で, 頻度は $0.4 \sim 2.6 \%$, 全例の平均は $1.3 \%$ ，おのおのの直 径は 3.1 5.2 $\mu$, 全例平均は $4.2 \mu$ であった. 対核径比 は 0.35 0.52, 平均は 0.45 であった. 未分化癌では, 頻度は $0.4 \%$, 直径は $14.5 \mu$ と乳頭癌に比し大きく, 対 核径比は 0.76 で増大した. 髄様癌 1 例では, その頻度 は $4.4 \%$ と最多で, その直径は $5.1 \mu$, 対核径比は 0.51 であった.

II. 各甲状腺疾患における核 DNA 量および総蛋白量 良性甲状腺疾患では，いずれも cellularity が低く， また, 細胞質の保持が不良である場合が多く, 計測細胞 数は悪性甲状腺疾患に比し限られた. 良性, 悪性を問わ ず, 囊胞液を含む穿刺材料では, 数回の等張液による洗 滌にもかかわらず, 背景の非特異的共染, あるいは細胞 変性のため計測不能であった.

慢性甲状腺炎では, 核 DNA 量は $2.21 \pm 0.63 \mathrm{AU}$ (mean $\pm \mathrm{SD}$, arbitary unit), $2 \mathrm{c}$ 域に major peak を有 した. 総蛋白量は, $2.60 \pm 0.97 \mathrm{AU}$ (mean $\pm \mathrm{SD}$ ), $2 \mathrm{p}$ 域 に major peak を有し(図 2, 表5), 両パラメーターは 有意 $(\mathrm{P}<0.05)$ な相関を示した.
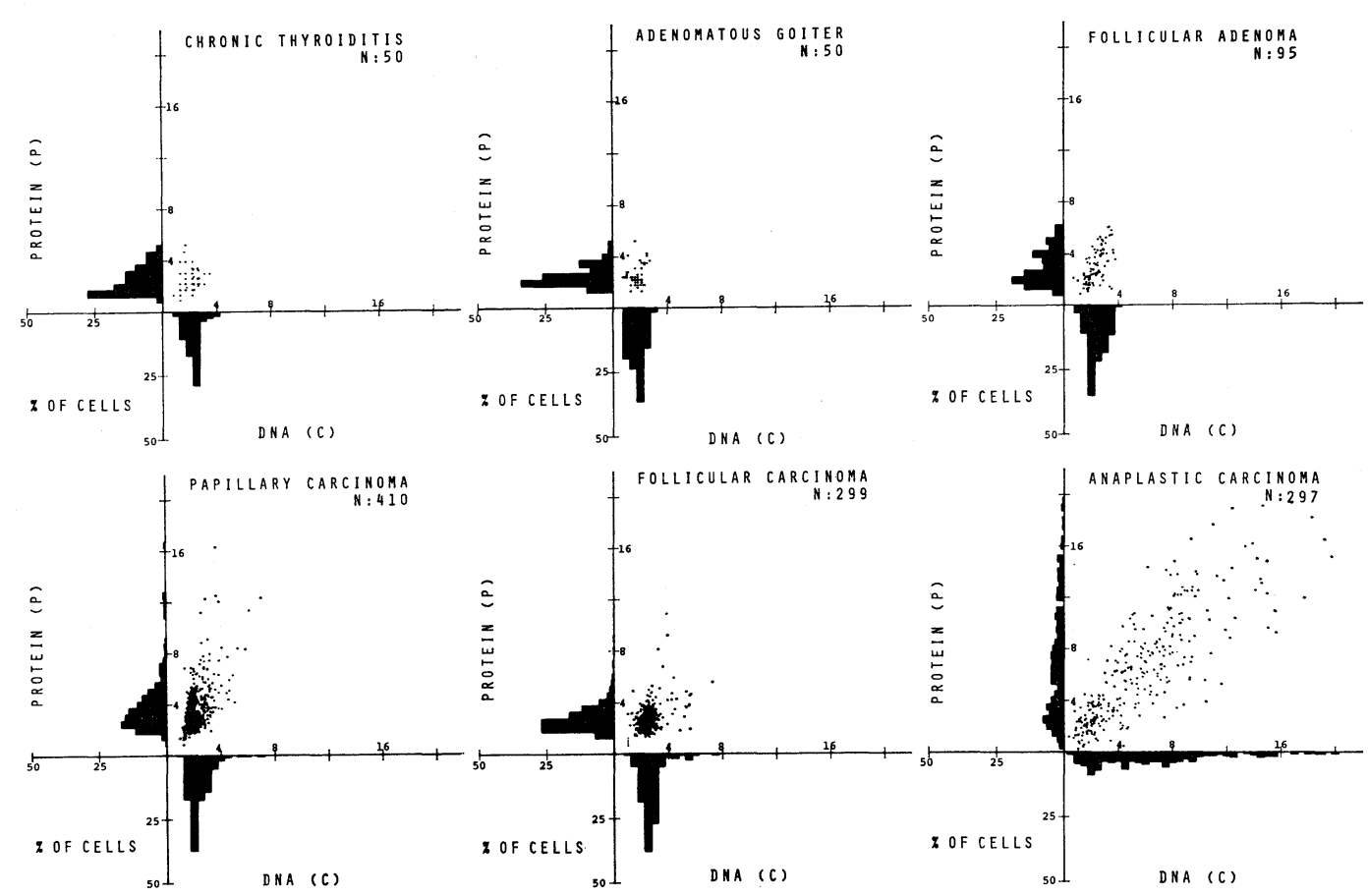

図 2 各甲状腺疾患における核 DNA 量および細胞総蛋白量散布図 
表 5 螢光顕微分光測光法による各甲状腺疾患の核 DNA 量および細胞総蛋白量

\begin{tabular}{|c|c|c|c|c|}
\hline & & $\begin{array}{c}\text { DNA } \\
\text { mean } \pm \mathrm{SD}(\mathrm{AU})\end{array}$ & $\begin{array}{c}\text { Protein } \\
\text { mean } \pm \mathrm{SD}(\mathrm{AU})\end{array}$ & 相関係数 \\
\hline 慢性甲状腺炎 & & $2.21 \pm 0.63$ & $2.60 \pm 0.97$ & 0.311 \\
\hline 腺腫様甲状腺腫 & & $1.81 \pm 0.50$ & $2.53 \pm 0.84$ & 0.188 \\
\hline \multirow[t]{3}{*}{ 濾胞腺腫 } & 1 & $2.09 \pm 0.30$ & $3.08 \pm 1.60$ & 0.693 \\
\hline & 2 & $2.40 \pm 0.67$ & $2.95 \pm 1.30$ & 0.651 \\
\hline & 3 & $2.25 \pm 0.83$ & $2.66 \pm 1.27$ & 0.438 \\
\hline 平 均 & & $2.28 \pm 0.65$ & $2.91 \pm 1.37$ & 0.522 \\
\hline \multirow[t]{5}{*}{ 乳頭癌 } & 1 & $2.61 \pm 0.66$ & $5.38 \pm 2.70$ & 0.819 \\
\hline & 2 & $2.22 \pm 0.95$ & $2.69 \pm 1.65$ & 0.777 \\
\hline & 3 & $2.35 \pm 0.78$ & $3.79 \pm 1.85$ & 0.522 \\
\hline & 4 & $2.83 \pm 0.93$ & $3.87 \pm 2.36$ & 0.420 \\
\hline & 5 & $3.11 \pm 1.10$ & $5.37 \pm 2.19$ & 0.755 \\
\hline 平均 & & $2.51 \pm 0.90^{*}$ & $4.01 \pm 2.35^{* *}$ & 0.641 \\
\hline 濾胞癌 & & $2.72 \pm 0.79^{*}$ & $2.78 \pm 0.99^{* * *}$ & 0.414 \\
\hline 未分化癌 & & $6.20 \pm 4.39^{*}$ & $6.70 \pm 4.81^{* *}$ & 0.836 \\
\hline
\end{tabular}

*濾胞腺腫核 DNA 量の平均值に対して有意 $(\mathrm{P}<0.001, \mathrm{t}$-test $)$

**濾胞腺腫総蛋白量の平均値に対して有意 $(\mathrm{P}<0.001, \mathrm{t}$-test $)$

***濾胞腺腫総蛋白量の平均值に対して有意差を認めない

腺腫様甲状腺腫では，核 DNA 量は $1.81 \pm 0.50 \mathrm{AU}$, $2 \mathrm{c}$ 域に major peak を示し, 総蛋白量は, $2.53 \pm 0.84$ $\mathrm{AU}$, major peak は $2 \mathrm{p}$ 域であったが, 有意な相関は示 さなかった（図 2，表 5).

濾胞腺腫では， 3 例が計測可能であったが，いずれも 孤立性上皮細胞は少なく, 計測細胞は限られた. 各例に

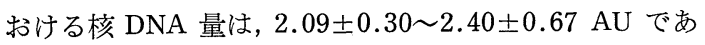
り, 全例の平均は $2.28 \pm 0.65 \mathrm{AU}$, major peak はいず れも $2 \mathrm{c}$ 域であった. 総蛋白量は, $2.66 \pm 1.27$ 3.08土 $1.60 \mathrm{AU}$, major peak はいずれも $2 \mathrm{p}$ 域であったが, 1例では, それに加え $4 \mathrm{p}$ 域に minor peak を示した (図 2, 表 5). 両パラメーターの相関はいずれも有意 $(\mathrm{P}<0.01)$ であった.

乳頭癌では, 各症例の核 DNA 量計測值は, $2.22 \pm$ $0.95 \sim 3.11 \pm 1.10 \mathrm{AU}$, 全例平均は $2.51 \pm 0.90 \mathrm{AU}$ であ った. 総蛋白量はそれぞれ $2.69 \pm 1.65 \sim 5.38 \pm 2.70 \mathrm{AU}$ と, 核 DNA 量に比し, 症例間の変動が大きく, 全例平 均は 4.01士2.35 AU であった (図 2, 表 5). 両パラメー ターの相関はいずれも有意 $(\mathrm{P}<0.01)$ であった.

濾胞癌では, 1 例に計測可能であった. その核 DNA 量 は $2.72 \pm 0.79 \mathrm{AU}$, 高 $2 \mathrm{c}$ 域に major peak を示した.

総蛋白量は, $2.78 \pm 0.99 \mathrm{AU}, 2 \mathrm{p}$ 域に major peak を示 し, 両者の相関は有意 $(P<0.01)$ であった (図 2 , 表 5 ). 未分化癌では, 孤立性癌細胞が豊富であった。 また, その測定に際し, 多核細胞も 1 個として計測した. 核
DNA 量は 6.20土4.39 AU とほかのいずれの例よりも高 值で, 明らかな peak をもたない異数性 aneuploidy を 示した. 総蛋白量も 6.70土4.81 AU と高值で, aneuploidy であった (図 2, 表 5). 両者の相関は有意 $(P<0.01)$ であった。

未分化癌細胞の核 DNA-蛋白螢光重染色における核 DNA 量および蛋白特異螢光像を写真 12 に示した。

これら各甲状腺疾患の両パラメーターの計測全データ についての Mahalanobis の汎距離法による 2 変量管理 図（図 3 ）では，慢性甲状腺炎および腺腫様甲状腺腫の 両パラメーターの計測值の $95 \%$ 確立散布範囲は, 近似 した，濾胞癌のそれは，良性疾患に比較し，やや右方へ の偏倚を示した，滤胞腺腫では，慢性甲状腺炎，腺腫様 甲状腺腫, 濾胞癌に比し, 上方へ偏倚する散布範囲を示 した. 乳頭癌では, 前 4 者いずれよりもやや広範な散布 であったが，総蛋白量の増量を示す上方への偏倚が著明 であり, 濾胞癌との対比では, 両者とも核 DNA 量は近 似するが, 乳頭癌では総蛋白量の増量がより顕著であっ た. 末分化癌は, ほかのいずれの甲状腺疾患とも類似し ない, 両パラメーターの広範な散布性を示した.

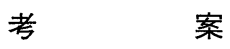

甲状腺腫の $\mathrm{ABC}$ は, 1952 年の Söderström の報告25) をはじめ, 以後, 多数の報告 ${ }^{13,18,28)}$ があり, 最近本邦に 

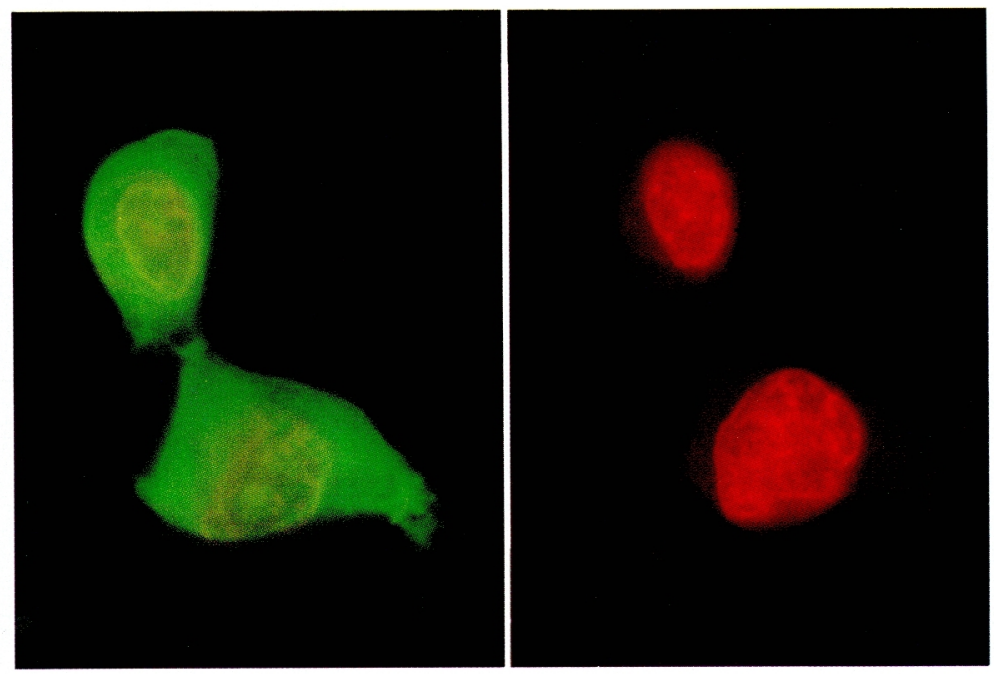

写真 12 未分化癌細胞における螢光重染色像. ninhydrin-acriflavine-Schiff 反応 による緑色蛋白特異螢光像 (左) および pararosanilin-Feulgen 反応に よる赤色核 DNA 特異螢光像 (右) $(\times 1,200)$

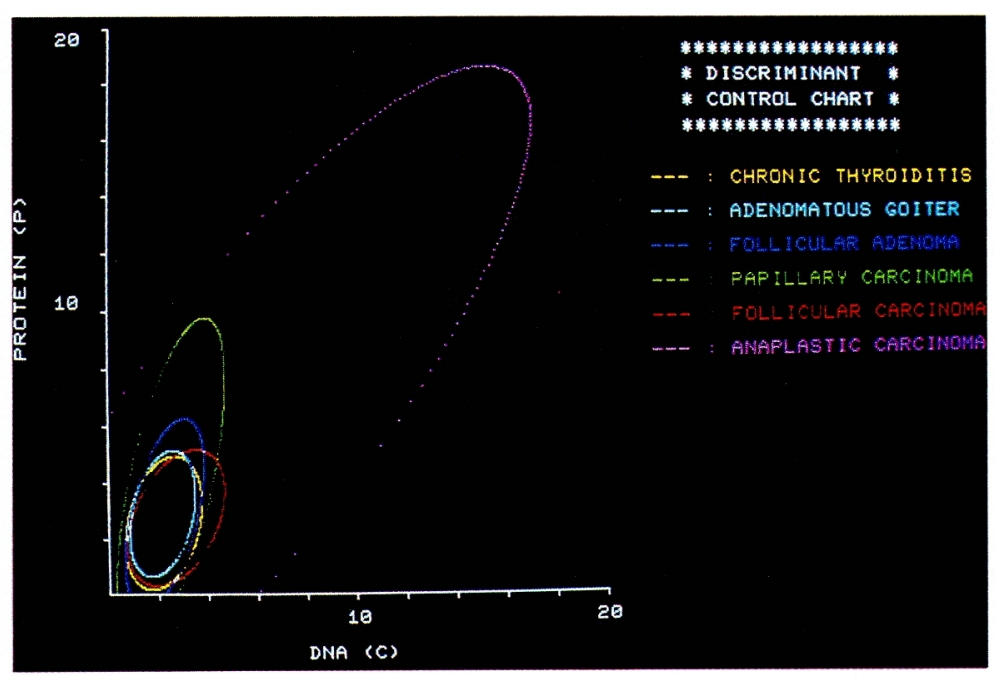

図 3 Mahalanobis の汎距離法による2 変量管理図. 色別された各曲線ば各甲状腺 疾患における核 DNA 量および細胞総蛋白量の $95 \%$ 等確立長円在示寸

おいても，多くの施設でその有用性が認識され，行われ ている.

\section{I. 甲状腺腫の $\mathrm{ABC}$ について}

甲状腺腫瘍は，乳腺腫瘍と同様に，体表より触知可能 でそその $\mathrm{ABC}$ も容易である.また，しばしば問題とさ れる針穿刺の安全性についても, Berg ら ${ }^{3)}$ は, 乳癌の $\mathrm{ABC}$ 例の長期生存率と非穿刺例のそれとの間に差を認 めないことをあげており, 甲状腺癌の $\mathrm{ABC}$ に関する報 告でも needle tract implantation および dissemination は経験されていない.この点について, Miller ら ${ }^{21)}$ は,
細針により採取された腫瘍細胞の viability の低下を示 唆している. 以上より細針による $\mathrm{ABC}$ は安全であると 考えられるが, より慎重に，穿刺針は可能なかぎり細針 を用いるべきであろう。穿刺針は，実際には21〜23 G の細針が適当である、本研究において, $21 \mathrm{G}$ の細針によ る $\mathrm{ABC}$ では, 細胞構築, cellularity も十分であった. 甲状腺腫では，しばしば囊胞変性を示すことがあり， Hammer $\check{b}^{9)}$ は, 甲状腺癌の $33 \%$ に霬胞変性を報告して いる. 本研究でも, 腺腫 37 例中 18 例, 乳頭癌 11 例中 3 例に囊胞变性を認めたが，これらの例では，単に露胞液 
の $\mathrm{ABC}$ のみでは, 腫瘍細胞数の減少, 細胞変性, 異型 を示す組織球などの増加等による, 疑陰性の一因となり うると思われた. 囊胞変性例の診断精度の向上のために は, 膜濾過法 ${ }^{27)}$ などによる確実な細胞収集が必要であろ う.また, 穿刺部位については, 事前の各種 画像 診断

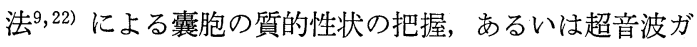
イド下による穿刺法などの応用も今後の検討課題である う.

\section{II. 各甲状腺疾患の細胞診所見について}

慢性甲状腺炎は, 組織学的に散在性と濔漫性に分類さ れ, 後者では, 諸種炎症性細胞浸潤, リンパ濾胞の形 成, 濾胞上皮の好酸性変性などの典型的な橋本病像を示 すものから, “硬化型, fibrous variant”17) まで, 組織学 的に広い spectrum を示す21). これら慢性甲状腺炎にお ける細胞診所見は, その個々の組織像の要素, すなわち, (1) 炎症性細胞浸潤の程度, (2) 滤胞上皮の多形性, (3) 間 質の線維化の程度などを反映するものである ${ }^{16,24)}$. 本研 究の慢性甲状腺炎 3 例でも, 諸種炎症性細胞の出現は, ほかの甲状腺疾患に比し, 明らかに増多したが, 症例間 のそれらの多宾は, それぞれの組織像をよく反映するも のであった. 滤胞上皮の核径計測值は, ほかの良性疾患 に比べ増大し, 症例間の差違を示した. これは各症例に おける濾胞上皮の変性の程度とよく相関し, 上皮の多形 性に起因するものと思われた.

腺腫様甲状腺腫および滤胞腺腫における細胞診所見で は, 前者において, 滤胞上皮数の減少傾向が認められた が，明らかな鑑別点は，諸家による報告 $13,21,28,30)$ と同様, みいだし得なかった. 核径の計測値も核の均一性を示し た.

乳頭癌における細胞診所見については, 多くの報 告13,18,21,22,28,29) があり, その細胞学的診断基準もほぼ確 立してきていると思われる. 乳頭癌の特徴的細胞診所見 として, Kini ら ${ }^{18)}$ は下記の 6 項目をあげている. すなわ ち, (1) papillary fronds, (2) monolayered sheets, (3) tissue fragments, (4) intranuclear cytoplasmic inclusions, (5) psammoma bodies, (6) multinucleated giant cells である. 上記所見に加え, 癌細胞の核径も, 慢性甲状腺 炎を除くほかの良性疾患に比し, 増大した. また, 多核 巨細胞と同様に，非特異的所見ではあるが, Miller ら ${ }^{21)}$ の記載した “vertical chromatin ridge” も, 比較的よ くみられる所見と思われた. 以上の所見に加え, 細胞診 における一般的悪性徴候の重要性は論をまたない，乳頭 癌は, 甲状腺悪性腫瘍の $76 \%{ }^{222)}$ と, 最も高頻度にみら れる癌であり，その早期診断における $\mathrm{ABC}$ の意義は, 今後さらに増大していくものと思われる.
濾胞癌は，高分化型では “ malignant adenoma” 称されるごとく, 組織学的にも腺腫との鑑別が困難であ り,この範疇の細胞診に関する諸家の報告 ${ }^{13,21,28,29)}$ でも， その限界を指摘されている. 本研究の 2 例の濾胞癌は, いずれも被膜への浸潤を示すものであったが, 1 例は “中 分化型”12) 濾胞癌であり, その細胞診所見も, クロマチ ン量の増加, 核小体の肥大, 赤染などの異型を示した. ほかの 1 例は, “高分化型”12) であり，その細胞診所見か らは, 腺腫との鑑別は困難と思われた。

多形細胞型未分化癌の細胞診所見は, 最も特徵的であ り，一般的悪性徴候を示すところから，その診断も容易 であり,むしろ $\mathrm{ABC}$ の非侵襲性, 迅速性が重要であろ う.

\section{ABCにおける核内封入体について}

1965 年の Kasten ら ${ }^{16)}$ の記載にはじまる甲状腺悪性腫 瘍の核内封入体は, その成因として, 腫瘍細胞の異常核 分裂が示唆されており ${ }^{24)}$ ，現在ではその $\mathrm{ABC}$ における 重要な悪性徴候の 1 つ考えられている. 本研究では, 乳頭癌の $91 \%$ に陽性であったが, これは，ほかの報 告 ${ }^{10,18)}$ と同様に高率であった. また，個々の例における 乳頭癌細胞中のその陽性頻度は, 平均 $1.3 \%$ と花輪ら ${ }^{10)}$ の報告と類似した。

核内封入体は，乳頭癌のみならず，ほかのいずれの癌 にもその出現が報告されている ${ }^{21)}$. 本研究でも, 滤胞癌 を除く甲状腺覀性腫瘍に陽性であったが，全甲状腺悪性 腫瘍に占める乳頭癌の頻度, 組織型別陽性率などからか んがみても，実際の $\mathrm{ABC}$ におけるその出現が乳頭癌を 一義的に示唆するという意見 $13,18,21,29)$ は, 妥当と思われ る.

\section{IV. 各甲状腺疾患における核 DNA 量および総蛋白 量について}

乳頭癌について, 阿部ら ${ }^{1)}$, 矢谷ら ${ }^{30)}$ は, 核 DNA 量の 増量を報告しており, 本研究の乳頭癌例でも, 腺腫例に 比較し, 有意な増量を示した. 一方, Johannessen .ら ${ }^{14)}$ は, この点に関して否定的である.

濾胞癌の核 DNA 量について, Lukács ら ${ }^{20)}$, Rabenhorst ${ }^{23)}$ は, 本研究と同様に, その増量を報告している. しかし, Sprenger ら ${ }^{26)}$, Johannessen ら ${ }^{15)}$ は，良性疾患 においてもその増量傾向を指摘し，その診断学的意義に ついては否定的である.

濾胞腺腫における核 DNA 量は, 癌との比較において 有意であったが, 乳頭癌例中でも, 腺腫より低值を示す 例もみられ，核 DNA 量のみからの鑑別は，慎重を期す べきであろう.

総蛋白量について, Caspersson ら ${ }^{6)}$ は, 悪性腫瘍にお 
けるその増量傾向を指摘し, 腫瘍細胞の核小体関連ク口 マチンの障害を, 総蛋白量の変動が間接的に反映するこ とを示唆している. また, Harada ら ${ }^{11)}$ は, 子宮頸癌にお ける核 DNA 量および総蛋白量の両パラメーターの間に 相関を指摘し, その生物学的悪性度と両パラメーターの 増量傾向が関連性を示すとしている. 本研究では, 乳頭 癌, 未分化癌で腺腫との間に有意差を認めたが, 濾胞癌 では，むしろ腺腫より減量を示しており，この面からの 鑑別には，さらに，核蛋白と non-histon 蛋白に分画定 量する必要性が示唆された.

乳頭癌および未分化癌では, 細胞採取性が良く, 細胞 質の良く保たれた孤立性細胞を得ることが可能であっ た.しかし，ほかの良性疾患では, cellularity, 細胞質の 脆弱性などの点から，十分な計測標本が得がたく, 対象 症例, 計測細胞数が限定された. これら固形腫瘍の preparation の確立は, 今後の顕微分光測光法における 課題であろう.

本研究の螢光顕微分光測光法による各甲状腺疾患の両 パラメーターの測定結果について, なお, preparation に 起因する症例間の測定值の変動, 誤差などを否定するこ とはできないが, 従来の細胞診所見における腫瘍細胞の 主観的なクロマチン量, 核細胞質量の変動を, これらの 測光法による客観化により, 詳細, 正確な解析が可能と なる点で有意義と考えられた.

\section{結語}

従来の Pap. 染色標本における各甲状腺疾患について, 甲状腺癌の診断に有用な, 特徵的細胞診所見について検 討した. 加えて, 客観的パラメーターとして, 各甲状腺 疾患における核長径の計測, 核内封入体出現頻度, おょ び螢光顕微分光測光法による核 DNA 量, 総蛋白量の測 定を行い, 疾患相互の比較検討を行った. これら多パラ メーターの解析が, 各甲状腺疾患, とりわけ癌の $\mathrm{ABC}$ において有意義であり, 今後, この分野におけるさらに 多くのパラメーターの検索, 診断への応用が必要と思わ れた.

本論文の要旨は, 第 24 回日本臨床細胞学会総会において発表 した.

\section{Summary}

Cytodiagnostic and cytofluorometric measurements of combined nuclear DNA and cellular protein contents were performed on epithelial cells taken by needle aspiration from 59 patients with neoplasms or other benign lesions of the thyroid. Analysis of other parameters, such as nuclear size and appearance of intranuclear cytoplasmic inclusions, was carried out on the malignant neoplasms. The conclusions of this study are as follows:

1. General cytologic property and nuclear size (100 cells)

Papillary carcinoma was distinguished by a papillary arrangement in all of 11 cases, and their nuclear size ranged from $7.8 \pm 1.4 \mu$ to $9.9 \pm 1.6 \mu$ (mean $\pm \mathrm{SD}$ ). Two cases of follicular carcinoma, which were more or less characterized by follicular pattern, were $8.3 \pm 1.3 \mu$ and $9.4 \pm 1.9 \mu$ in nuclear size. Anaplastic carcinoma, though only one case, showed marked nuclear atypism and anisonucleosis, and measured $10.7 \pm 2.9 \mu$ in nuclear size. In 2 cases of medullary carcinoma, their nuclei measuring $8.5 \pm 1.6 \mu$ and $9.0 \pm 1.8 \mu$ in nuclear size, were in the same range as those in the other types. Thirty seven cases of follicular adenoma resembled follicular carcinoma so far as morphometry concerned, and their nuclei varied $5.5 \pm 0.7 \mu$ to $7.2 \pm 0.7 \mu$ in nuclear size. Three cases of adenomatous goiter were also similar to follicular adenoma in cytological features, their nuclear size ranged from $6.0 \pm 0.6 \mu$ to $6.6 \pm 0.8 \mu$. Chronic thyroiditis was studied in 3 cases, the epithelial cells were associated with a number of various inflammatory cells. In general, oxyphilic cells exhibited rather striking nuclear atypism. The nuclei disclosed fairly variable sizes ranging from $7.1 \pm 1.2 \mu$ to $9.2 \pm 2.0 \mu$.

2. Intranuclear cytoplasmic inclusions

Inclusions were observed in 10 cases $(91 \%)$ of 11 papillary carcinomas. The frequency of inclusions ranged from $0.4 \%$ to $2.6 \%$. They were also observed in one of one anaplastic carcinoma and one of 2 medullary carcinomas, and frequencies of which were $0.4 \%$ and $4.4 \%$ respectively. No inclusions could be found either in the benign lesions or in follicular carcinomas.

3. Nuclear DNA and cellular protein

Both DNA versus protein contents (mean $\pm \mathrm{SD}$ ) were $2.21 \pm 0.63 \mathrm{AU}$ (arbitrary unit) $: 2.60 \pm 0.97 \mathrm{AU}$ in chronic thyroiditis, $1.81 \pm 0.50 \mathrm{AU}: 2.53 \pm 0.84 \mathrm{AU}$ in adenomatous goiter, $2.28 \pm 0.65 \mathrm{AU}: 2.91 \pm 1.37 \mathrm{AU}$ in follicular adenoma, $2.51 \pm 0.90 \mathrm{AU}: 4.01 \pm 2.35 \mathrm{AU}$ in papillary carcinoma, $2.72 \pm 0.79 \mathrm{AU}: 2.78 \pm 0.99 \mathrm{AU}$ in follicular carcinoma, and $6.20 \pm 4.39 \mathrm{AU}: 6.70 \pm 4.81 \mathrm{AU}$ in anaplastic carcinoma. Discriminant control chart based on Mahalanobis' generalized distance of papillary carcinoma and anaplastic carcinoma showed wider distribution in the protein content than those of other benign lesions and 
follicular carcinoma. In the anaplastic carcinoma, the discriminant control chart was that distributed more extensively than in all the other thyroid lesions.

Cytofluorometric measurements of combined nuclear DNA and cellular protein contents in addition to other parameters, i.e., nuclear size and intranuclear cytoplasmic inclusions, were considered to be useful as the objective parameters, especially in aspiration biopsy cytology of the thyroid lesions.

\section{文献}

1）阿部庄作・他：核 DNA 量による甲状腺腫穿刺細胞診断, 日臨細胞誌, $20: 8 \sim 14,1981$.

2) Auel, G.U., et al. : Comparison of DNA distributions in primary human breast cancers and their metastases, Europ. J. Cancer, $16: 273 \sim 278,1980$.

3) Berg, J.W., et al. : A late look at the safety of aspiration biopsy, Cancer, $15: 826 \sim 827,1962$.

4) Böhm, N., et al. : DNA in human tumors; a cytophotometric study, Curr. Top. Pathol., 60 : 151 219, 1975.

5) Caspersson, T. : Cell growth and cell function, Norton, New York, 1950.

6) Caspersson, T., et al. : Cytochemical differences between mammalian cell lines of normal and neoplastic origins, Exp. Cell Res., $32: 553 \sim 565,1963$.

7) Fujita, S., et al. : Simultaneous measurement of DNA content and grain count on an autoradiographs of Feulgen stained cells, Histochemistry, 40 : 155 163, 1974.

8) Fukuda, M., et al. : Combined protein and DNA measurements by the ninhydrin-Schiff and Feulgen techniques, Histochemistry, $63: 35 \sim 45,1979$.

9) Hammer, M., et al. : Cancer in cystic lesions of the thyroid, Arch. Surg., $117: 1020 \sim 1023,1982$.

10）花輪孝雄・他：甲状腺疾患における核内封入体の臨床細胞 学的検討, 日臨細胞誌, $18: 302 \sim 311,1979$.

11) Harada, K., et al. : Combined DNA and protein cytofluorometry of gynecological smears;-Quantitative identification of tumor cells and discrimination of intraepithelial neoplasia from invasive cancer-, Acta Histochem. Cytochem., $14: 24 \sim 34,1981$.

12) Hedinger, C., et al. : Histological typing of thyroid tumours, International histological classification of tumours, No. 11, World Health Organization, Geneva, 1974.

13）庵原昭一・他：穿刺吸引細胞診からみた甲状腺 癌の細胞 診, 日臨細胞誌, $16: 43 \sim 55,1977$.
14) Johannessen, J.V., et al. : A flow cytometric DNA analysis of papillary thyroid carcinoma, Lab. Invest., $45: 336 \sim 341,1981$.

15) Johannessen, J.V., et al. : The diagnostic value of flowcytometric DNA measurements in selected disorders of the human thyroid, Am. J. Clin. Pathol., $77: 20 \sim 25,1982$.

16) Kasten, F.H., et al. : Cinematography, phase-contrast and fluorescence microscopy of human thyroid tumors in tissue culture with observations of virous like lesions, Tex. Rep. Biol. Med., 23:337 347, 1965.

17) Katz, S.M., et al. : The fibrous variant of Hashimoto's thyroiditis, Human Pathol., $5: 161 \sim 170,1974$.

18) Kini, S.R., et al. : Cytopathology of papillary carcinoma of the thyroid by fine needle aspiration, Acta Cytol., $24: 511 \sim 521,1980$.

19）甲状腺外科検討会編：甲状腺癌取扱い規約, 金原出版, 東 京, 1977 .

20) Lukács, G.L., et al. : Cytofluorimetric measurements on the DNA contents of tumor cells in human thyroid gland, J. Cancer Res. Clin. Oncol., $95: 265 \sim 271$, 1979.

21) Miller, J.M., et al. : Needle biopsy of the thyroid, pp. 2 125, Praeger, New York, 1983.

22）小原孝男・他：甲状腺悪性腫瘍, ホルモンと臨, $32: 61$ 72, 1984.

23) Rabenhorst, G.: The diagnostic value of the DNA content of fine needle biopsies of the thyroid gland, Arch. B. Cell Path., $16: 379 \sim 382,1974$.

24) Sobel, H.J., et al. : Nonviral nuclear inclusions, I. Cytoplasmic invaginations, Path. Lab. Med., 87 : 179 $\sim 192,1969$.

25) Söderström, N. : Puncture of goiters for aspiration biopsy, Acta Med. Scand., 144 : 237 244, 1952.

26) Sprenger, E., et al. : Differential diagnosis between follicular adenoma and follicular carcinoma of the thyroid by nuclear DNA determination, Acta Cytol., $21: 528 \sim 530,1977$.

27) Takahashi, M. : Color atlas of cancer cytology, 2nd ed., pp. 57 82, Igaku Shoin, Tokyo, New York, 1981.

28）鳥屋城男：甲状腺腫の穿刺吸引細胞診一特にその病理組織 像と細胞像の対比について一, 日 臨 細胞誌, 11:101 $114,1972$.

29）矢谷隆一・他：甲状腺腫の擦過塗抹細胞診, 日臨細胞誌, $15: 156 \sim 167,1976$.

30）矢谷隆一・他：甲状腺結節性病変における核 DNA 量解析 の診断的意義, 日臨細胞誌, $20: 1 \sim 7,1981$. 